\title{
The Film Document \\ as a Testimony of the Present: A Sceptic at the Confessional
}

Images

vol. XV/no. 24

Poznań 2014

ISSN 1731-45OX

"An ordinary tape of celluloid, lit up, is not only a historical document but also a part of history - a history that has not died and whose resurrection does not require genius. [...] One can boldly claim that the so-called living photograph has features of authenticity, precision and exactness that only it possesses. It is an eyewitness par excellence, one that is believable and infallible".[1]

Bolesław Matuszewski, 1898

"One can describe a cinematographic work in four words: the eye that sees". [2]

Dziga Vertov, 1923

"So far we have regarded all films made from natural material as coming within the category. The use of natural material has been regarded as the vital distinction. Where the camera shot on the spot [...] in that fact was documentary. [...] They all represent different qualities of observation, different intentions in observation, and, of course, very different powers and ambitions at the stage of organizing material'”[3]

John Grierson, 1932-1934

"What is a documentary film? Its first and principle trait is what its name already holds. This should be the film-document. Documentary - it is in this description that it is most often understood - as true". [4]

Andrzej Munk, 1962

[1] B. Matuszewski, Une nouvelle source de l'histoire (Création d'un dépôt cinématographique), Paris 1898. Polish translation: Nowe źródło Historii, trans. B. Michałek, in: Europejskie manifesty kina. Od Matuszewskiego do Dogmy, red. A. Gwóźdź, Wiedza Powszechna, Warszawa 2002, p. 36.

[2] D. Vertov, „O znaczeniu kinematografii niefabularnej" [On the Meaning of Documentary Cinematography], in: Człowiek z kamerą. Wybór pism, trans. T. Karpowski, Wydawnictwa Artystyczne i Filmowe, Warszawa 1979, p. 38. Original: Д. Вертов,
О значении неигровой кинематографии, Moskva 1923.

[3] J. Grierson, "Dokumentalizm (fragmenty)", trans. Andrzej Kołodyński, in: Europejskie manifesty kina..., p. 264. Original: Grierson on Documentary, University of California Press, 1966, p. 145.

[4] After S. Janicki, "Andrzej Munk", in: Polscy twórcy filmowi o sobie [Polish Filmmakers on Themselves], Wydawnictwa Artystyczne i Filmowe, Warszawa 1962, p. 58. 
"And all the while, we are concerned with a sensitive and continually open investigation of reality - not illustration but one of its unveiling".[5]

Kazimierz Karabasz, 1979

"The Communist world was not recorded - in other words it was recorded as it ought to be and not as it was in truth. We - there were many of us - attempted to place it on record. This proved to be fascinating. This is similar to the feeling that accompanies the act of birth. A little as if when something is not described, it then in fact does not exist. If we begin to record it, we shall in some sense bring it to life".[6]

Krzysztof Kieślowski, 1995

"For we continue to learn all the time and every film is another defined experience. For me documentary film is also a concrete experience. I - and the other".[7]

Sergei Loznitsa, 2013

Seven comments spanning the history of film - 1898, 1923, 1934, 1961, 1976, 1995, 2013 - seven different film anima but... For 115 years documentary filmmakers, each using a different text, speak in fact about the same thing. If read together, these comments fall into place in a surprisingly coherent intellectual metatext.

How is it that during reception and in the process of communication, moving visual and sound pictures become a type of recording of the real world? There is no easy answer to what would appear to be a simple question. The recording of visual and audio images of the real world from the very beginning of the existence of cinema was founded by a convention based on a presentation of extreme realism of not only of people and objects, but also situations taking place in the presence of the film camera.

Documentary narration and film is based on the participation of a singular arrangement of the narrative present (praesens historicum) where the filmed present, a moment later changes into a record of the past.

The major aspect of this genre convention - the integral nature of all documentary information, regardless of the poetics concerned, degree of participation of stage production etc - is marked out by the referential function; the caveat being in this context that this concerns not an image that is completely free but only one whose aim is to show a defined fragment of reality. The documentary transfer as well, in its

[5] K. Karabasz, Cierpliwe oko [The Patient Eye], Wydawnictwa Artystyczne i Filmowe Warszawa 1979, p. 51.

[6] K. Kieślowski, O sobie [Kieślowski on Kieślowski], Znak, Kraków 1997, p. 49.
[7] S. Loznitsa, Autentyczność i fenomen kina [Authenticity and the Phenomenon of Cinema], Masterclass lecture conducted during Planete-Doc Festival, Warszawa 2013. 
wide range of genres and variations, exists so as to communicate by means of a series of moving images something that in reality has occurred, in relative terms (as in the case of live television transmission) that in fact at this very moment takes place.

From the very beginning of cinema up to the present day, the reality presented on screen has been one that is mediated. This claim embraces two concepts in one. First, it signals that the documentary as a form of communication and information has, one way or the other, a personalised nature; equally for the so-called sender and the receiver. Secondly, every such documentary message has something to communicate in the language of moving images and thereby to its system properties. It therefore draws from its means of expression and subsequently by means of a defined language convention (communicative) that belongs to the language system of moving images.

Clearly, it would be desirable that in our day and age - in the face of widespread access to various cinematographic documents which the latest media have managed to accustom us - the standard mass awareness in respect to the agreed nature of documentary 'information' has increased. Moreover, the aspect of conventions has become a commonly accepted fact. In addition, there is the hope that the community of those once believing in reality per se is declining, and those sceptical of the image, is rising. Alas, this is not so. The mediation of the symbols and semiotic conventions of documentary film and audiovisual forms continues to be seen and understood by only a very small part of the audience. The remainder continues to be more or less uncritical and trusting.

It is worthwhile in this place to revisit and reconstruct the complex road that documentary film has taken over the past century. Through the course of time, the means of the perception of moving images has unnoticeably and organically transformed into an integral part of culture. The cinematographic symbol has become material, a part of society. Nonetheless, one sees and hears the phantoms of the screen, trusting their 'credibility' and 'truthfulness'. When we are before the big screen, we continue to remain naive and gullible, as if part of a pioneer audience, in the thrall of the Lumière brothers, fleeing before the speeding locomotive rushing straight at us.

The documentary 'message' on the screen from the very beginning has had the effect of observing something real. So it is too to this very day, in times when it is not difficult to produce a digital simulacrum that appears to be the real world, with its respective elements and processes. As established participants of the cinema, television, the Internet and mobile phones, as in times of yore, we are prepared to believe in living images as a credible testimony of the events shown. Fortunately, not all of us do believe, but without doubt there are many such believers.

It can be said that information in its contemporary form of media has been subject to a dangerous inclination towards the banal and predictability. Man in the 21st-century as a passive consumer of 
information has to a large degree lost his sense of enquiry, as well as sensitivity and ability for critical thinking; everything is accepted and nothing surprises. Contemporary man is incessantly at the epicentre of information but very rarely is in fact well-informed. The progressive erosion of actual subject matter conveyed is responsible for a total (this adjective is decidedly apt) simplification and 'fast food' vision of the world, served up courtesy of various communication channels.

The basic conflict, not only in Polish documentary film and others, is the issue of the contents of the so-called message. For some the box under the name 'what' signifies almost a measurable market appeal that results from a defined means of creating the image of reality. For others, this particular box is associated with the search for truth and the discovery of the complex world outside, in which we live. This rarified and social conflict represents the following ongoing tensions:

1) between a tabloid simplified view and one that has a range of meanings and values in the creation of screen information and

2) between a passive (one of acceptance) and active (discursive) style of reception.

It would not be a mistake to venture that the essence of the matter in the above 'conflict' can be reduced to two positions - uncritical versus critical.

In what respect is tabloid news different from the documentary version of information in relation to the same subject? It would appear, nothing. Both forms of information, after all, are the same. On further reflection - not only the 'what' is important but also the 'how' (in what way) it informs? Tabloid news and documentary accounts differ in general in respect to two so-called markers; first, the degree of complexity in the communication, and second, the sender's relation to the addressee. Thus, they differ potentially a great deal, in fact to a very significant extent. So as to see this basic difference between one and the other, it is enough to enquire about the vision of the world encoded in the transfer of information and read the deeper meaning of this comparison in terms of the information on the anthropology of culture.

The news items in tabloid media, regardless as to their form: newspaper, illustrated magazine, radio, cinema, television, the Internet or mobile phone, offer, the 'audience' a pre-prepared vision stripped of all complexity, and simplified - of the world outside. Its typical traits are a bipolar approach (based on a polar contrast of conceptions such as we-they, good-bad, ours-theirs) and further-explicitness (the world you live in really is this) and a 'totality' (this is the whole 'truth' that we present) - while at the same time there is the exclusion of anything in anyway more complex, which does not fit into the framework of the schematized picture of the world in the most simple way.

The common access of millions of people to various sources of information has become an integral part of culture and a singular 
symbol of contemporary civilization. These can take the form of information that is verbal, visual, audio and audiovisual, made available daily, and that which is provided by the minute in the media. The world outside is today documented and recorded 'live'. Information on events appears immediately and in the case of television broadcasts or the use of mobile phones, at the same time.[8]We live in the world of media, make constant use of their channels and are users of an almost omnipresent macro system of communication.

Organised in such a way and functioning to this very day, the information profession defines the present situation of all documentary work. The documentary filmmaker, engaged in cinema, who has something to say on important matters, has to constantly define his position in relation to the actual documentary context and related circumstances. It is in this particular way that the documentary filmmaker defines his own work afresh. The field of battle being waged in the so-called info-sphere is in this context one and the same each time - the language of moving pictures. This language represents a developed system of communication that each of the participants in their own way uses, creating and modelling their message in its banal and routine form or, in contrast, as one of discovery.

The basic conceptual category that is made large in the title of the study represents the present world of the screen understood as one that is filmed (documented) here and now.

In actual fact the above can be said to amount to a correlation of three states of the present. One is created by the actual moment of camera operation, the second - the ongoing time of the event being filmed (taking on the conventional nature of praesens historicum in the plan of narration) - and the third, the moment of projection. In all three situations the quintessence of the process of communication is represented by the defined modelling by the sender of the so-called transfer of images and pictures of the presented reality in question.

The semiotic mechanism of presenting the present time has remained the same from the 19th century up to this very day. This is governed in every cinematographic transfer of information without exception by the choice and combination of visual and audio elements shown on the screen, as well as the associated operation of the fragmentation and segmentation of the images of reality being communicated. Taking as an example a single shot being framed, it can be seen that this operation at the same time is based on the choice and arrangement of a given presentation of reality being documented.

The fragmentation and segmentation (terms introduced a decade ago to film studies by Canadian scholars) [9] as inseparable and

[8] U. Eco, "Przypadek i intryga (Doświadczenia telewizji a estetyka)", trans. A. Kreisberg, in: Dzieło otwarte. Forma i nieokreśloność w poetykach współczesnych, Czytelnik, Warszawa 1973, pp. 194-219. Original: U. Eco, Opera aperta: forma e indeterminazione nelle poetiche contemporanee, Bompiani, Fabbri 1989. [9] A. Gaudreault, J.-M. Lamotte, T. Barnard, "Fragmentation and segmentation in the Lumière 'Animated Views"', The Moving Image 2003, no. 3. 
complimentary processes, represent two fundamental and strictly mutually correlated editing operations that occur in a given process of communication by the means of moving images.

The transfer of information therefore becomes a document that fulfils the function of relating what has occurred (or in fact is to occur) in a defined place and time. In other words, it documents reality. The question, however, arises as to what type of reality. Among many possible answers this author chooses one, namely the reality that has become the work of the filmmaker. It is one the filmmaker has seen, heard, in a given moment experienced, personally worked with and recorded. The documentalist also - as the conveyor of the message - carries the responsibility of its contents and form.

According to Jacek Ostaszewski: "If one is to recognise that the basic aim of communication is to present information, then undoubtedly film from the dawn of its inception was the medium of information and served to communicate".[10] Although the article of the Kraków Film Studies scholar is focused on cinema fiction with a particular emphasis on the artistic, there is nothing that speaks against its views and thesis also being related to the transfer of information that is non fiction. The latter after all, in the era of silent film was often works of film art, clearly belonging to the sphere of artistic communication. Such, too, is the case in the practice of a creative film documentary up to this very day.

The type of information contained in moving pictures is by nature one of informing that links in its very self the experience of the world, the experience of civilisation and that of culture.[11]Understood in this way, information on the process of informing reaches a level of meaning and dimension that is par excellence anthropological. It is therefore a broadly understood experience by man and society - independent of changeability and the ad hoc nature of subjects raised in a given piece of information - one that represents its so-called what and so-called how each time. One can say that every time the very same thing is important - the difference of the potential between what is known and that which is not. The documentary being made appears in each instance as a mutual discovery of a known or unknown reality, both by the filmmaker and the audience.

The cultural dimension of information (in this respect regardless whether it is verbal, visual, audio or audiovisual) contains a memory of the world recorded in the text of culture and a knowledge of the unknown that is not recorded in any form of information or indeed expressed up to now. The unknown that remains in the film is made present to the audience. It is in fact this value of recording the unrecorded reality that four decades ago the New Wave poets Julian Kornhauser

[10] J. Ostaszewski, Film jako komunikat [Film as a Communication], in: Komunikacja wizualna, ed. P. Francuz. Wydawnictwo Naukowe Scholar, Warszawa 2012.
[11] See R. Nycz, Poetyka doświadczenia. Teoria nowoczesność - literatura [The Poetics of Experience. Theory, Modernity and Literature], Instytut Badań Literackich PAN, Warszawa 2012. 
and Adam Zagajewski[12]and documentalist Krzysztof Kieślowski[13] brought to our attention.

The credibility of moving pictures is not a given. It represents as much intentional as inter-subjective forms of the information made available in communication. As such, it becomes the subject of an unwritten but binding agreement for both sides - between sender and receiver. It is not present in the cinematographic text itself (as believed Bolesław Matuszewski and a long chain of his followers afterwards). It exists, however, (or does not exist) in the communication expressed by means of the language of moving images - as a phenomenon and symbolic consequence, meaning one that demands a semiotic mediation of the symbol, as well as interaction between the sender and receiver.

The conflict of documentalists with television was not born only yesterday. It has existed for a very long time - both in Poland, as well as abroad. The so-called conflict over the language of the documentary is at the same time one about the picture of reality as well as about the nature of its conceptualisation. Various documentary filmmakers and various television stations resolve this in a particular way through a process of unending discussion and negotiation. The arguments and who is right can be said to lie on both sides. Everything would seem to point to the fact that this long-standing conflict cannot be resolved or definitively eliminated. Its source can be said to be the very nature of collective communication and its complex mechanism, one whose social, psychological and cultural work is governed by its own rules.

In this system a reporter working for a given station with a camera that relates ongoing events is someone other than a documentalist creating a greater or lesser authorial announcement on the contemporary world outside. Both the reporter and the documentalist in this context produce in fact a documentary 'message' but each in a different way. The above mentioned conflict does not only concern television but also occurs in various other spheres of the documentary, everywhere - where there arises the fundamental question of the truth and believability of the information presented.

Documentary work as always - equally today - signifies the need to undertake the same decisions and to make the same ethical choices that belonged to documentary filmmakers many decades ago. The tools of the trade have changed, as has the equipment, technology of production, recording, editing, processing and transmission of moving images. Sound and colour have since been added. Former styles of narration have changed across time as have the means of film expression. This is, however, a matter of replacing one set of instruments with others and, as a result, producing another change of poetics in the contemporary documentary.

[12] J. Kornhauser, A. Zagajewski, Świat nie przedstawiony [The World Yet to Be], Wydawnictwo Literackie, Kraków 1973.
[13] K. Kieślowski, "Dwie rozmowy - wywiad nie do druku" [Two Talks - Discussion, Not Publication] discussion with A. Kołodyński (14 grudnia 1973), Kino 1996, no. 5 . 
The very nature of this profession has remained in fact the same as in the past. The contemporary documentary filmmaker creating his work in the 21st c. - just as his cinematic forebears making documentaries in previous periods of cinema history - is fated to a constantly repeated battle with the odds - a latter day Sisyphus fated to constantly push an enormous boulder uphill. The work of documenting a part of the world with the aid of a camera, continually starting anew, represents its fundamental experience in terms of the professionalism and creativity.

This is no myth - but reality itself. 